\title{
Origin of Foreign Direct Investments
}

\author{
Ph.D.C. Aida Saraçi \\ Municipality of Elbasan \\ Email: aida.saraci@yahoo.com
}

\section{Doi:10.5901/mjss.2014.v5n7p48}

\section{Abstract}

Since ancient times people moved from one place to another with the purpose of exchanging goods of a country with those of another one to attain what was missing in the country where they lived. These first exchanges were product to product and latter was introduced in circulation on the money as exchange to the product. These first forms of trading were increasingly altered even more today where capital moves from one country to another. Foreign Direct Investments, FDI is a relatively new phenomenon in the entire globe. This phenomenon that has affected global economic growth and improved living standards, received notable development in the XXI century in the form of loans that English economy uses to finance economic development in different countries as well as in the form of ownership of financial assets. Developments of the early XXI century are demonstrating that in this globalized world the opportunities for trading exchanges, for providing quality services without frontiers of languages or distances, are without limits and extraordinary. There are many different theories developed over the years in order to give explanation the creation or appearance of multi- national enterprises. These are divided into two groups: macroeconomic theory that tries to give an explanation in terms of general economic and microeconomic theory that seeks to find a different explanation in terms of the individual in which an enterprise operates. Therefore all the theories that have been examined so far cannot be considered as general theory of investments. Each one of them starts from different assumptions and explains various aspects of the phenomenon, thus we are talking about a partial theory.

Keywords: investment, theories, exchanges, trade, economy.

\section{Introduction}

Since antiquity people moved from one place to another with the purpose of exchanging goods of a country with those of another country to achieve the attainment what was missing in the country where they lived. These first exchanges were goods with goods then after money came into circulation and there was no more the commodity exchange but commodity with money. These initial forms of trading were increasingly altered until today where capital moves from one country to another.

In 1776, philosopher and economist Adam Smith gave an optimistic conclusion on the analysis of the nations' wealth on the threshold of an industrial expansion in England. According to him "No society can flourish and be happy if a large proportion of its members are poor and miserable". 1

Foreign Direct Investments are relatively a new phenomenon across the globe. This phenomenon has affected the growth global economy and improvement of the living standards, and has received notable development in the nineteenth century in the form of credit that makes the English economy to fund economic development in different countries and in the form of ownership of financial assets. In the period between the two wars in the twentieth century, foreign investments had a significant decrease. The end of World War II marked the flourishing of the phenomenon of FDI for two main reasons. Firstly, the development of technology favored transport and communications which enabled the possibility of control in distance as a condition for the development of FDI. Secondly, Europe and Japan needed the capital of United States of America for reconstruction. In this period U.S.A. adopted a tax system that favored foreign investments.

Recent developments of the early XXI century are proving that in this globalized world of opportunities for trade exchanges, the provision of quality services without frontiers of languages or distances have no limits and are extraordinary. What motivates today economic operators to conduct foreign direct investments is the desire to take control of a certain production activities abroad, naturally without forgetting another very important factor which is economic benefits. This phenomenon has attracted the attention of many social factors, political and mainly economical.

There are several definitions for "Foreign Direct Investments". The definition which given to us by the International

\footnotetext{
${ }^{1}$ Velia V. , Për ku je nisur Shqipëria ime?, 1996.
} 
Monetary Fund in 1993 is: "Direct Investment is an investment involving a long-term relationship and reflecting a lasting interest in an entity that operates and stays in one place (the investor) in an economic entity that diverts to another place that is different from where the investor is resident."

Another definition is their consideration as net access of investments to ensure sustainable interest in management of an economic entity that operates in a country different from that of the investor.

The ultimate goal of direct investment is to have a high influence on the direction of a company that is established in another country where the investor is not resident.

Various theories have been developed over the years to explain the creation or appearance of many multinational enterprises. They are divided into two groups: macroeconomic theory that tries to give an explanation in terms of general economic and microeconomic theory that seeks to find an explanation in different individual terms in which an enterprise operates. ${ }^{2}$ In the first group of the macroeconomic theories, it's definitely worth to mention the contribution that Mundell (1957) has given who starting from the early beginnings of neoclassical theory and in particular the international trade by Heckcsher - Ohlin Samuel ( HOS ) model, and eliminating one of the basic assumptions of the model, namely the international immobility of factors of production, explains the emergence of multinational companies. For Mundell, the initial imbalance between two or more countries caused by factors of production can be eliminated through international trade or the internationalization of production. This means that the state does not necessarily specialize in the production of capital - intense goods with greater availability of capital, making it possible to export and use the capital where there is more absence. According to Mundell, multinational company is an alternative process of specialization. Evermore it's worth mentioning the contribution given by Kojima (1978) in the context of neoclassical theories of international trade. He also explains the phenomenon of multinational companies through domestic factors, especially capital factor.

The concept of capital to which the author refers, however, is different from that of the capital in the financial sense. He refers to the concept of physical or intangible capital, meaning the group of all those technological and organizational structures that a country possesses.

According to Kojima, taking into account the two countries, the direct investment is realized by the company that the country has competitive advantages in the production of material goods in comparison with the other country whose advantages arising from knowledge of particular technological and / or organizational practices that the host country does not possess. ${ }^{3}$

At the same time, the country in which the investment was made has other competitive advantages in the use of the produced goods. It is clear that it refers above all in the production of intermediate goods. Consequently, if the concept of intangible capital recognizes the technology available in a country, in reality this theory can also be considered a variation of the model $\mathrm{H}-\mathrm{O}-\mathrm{S}$ with which the hypothesis of identical production functions is abandoned. ${ }^{4}$

In the second group of microeconomic theories, the contribution given by Hymer (1960) is part of it. In this case, the attention is shifted to the individual company, in particular in the choices made by the latter and the reasons that justify these choices. According to the author, for the company that decides to start productive activities abroad, inevitably there are advantages that can be associated with the production of goods, sales or enterprise. All of these make it possible to face the best competition that comes from businesses of the host country regardless of disadvantages that may arise from the exercise of the activity in a "foreign land ". These advantages exist not for every enterprise that operates in a closely related sector. They are closely related to a specific company.

Even though that author has not expressed sometimes, in the theory of Hymer we can see the phenomenon of multi-nationality, the idea originally was introduced by Coase (1937) as an alternative to the enterprise market for companies that are placed where market failure is verified. It is precisely this idea that stands at the basis of the theory that was developed after "the theory of internationalization " ( Buckley and Casson , 1976).

In this case it is considered essential to the existence the advantages of ownership, but it's enough to be present a form of inefficiency allocated in the market. This lack of efficiency makes it more convenient or less expensive for the realization of international transactions of goods within the framework of the firm benefits rather than external market. This theory seeks to explain the phenomenon of vertical integration of production rather than the horizontal one.

Phenomenon of vertical integration of production can be explained by the need of the company to provide raw material without risks of encountering the unexpected or blocked quantities or unexpected fluctuations, as well as to ensure control in stage of the sales produced goods. The second phenomenon of the horizontal integration can be

\footnotetext{
${ }^{2}$ Caves R.E., Multinational enterprise and economic analysis, Cambridge University Press, Cambridge, Massachussets, 1996.

${ }^{3}$ Kojima K.., Direct Foreign Investment: A Japanese Model, 1978.

${ }^{4}$ Gianneti M., Movements of financial capital and production , 2000.
} 
explained by facilities for economic benefits outside the main activity that allow the benefits of the activity as a whole.

Always focusing on the election of a single firm it is introduced the theory of "production cycle". Dividing the " life cycle " of the product in three phases, we can be confirmed that production activity is located in the host country and the market where they wish to serve their products as well as a place where there is the technology necessary for the realization of the production process of the product.

In a second stage, when they have provided a significant control in the domestic market, they begin the production to meet market demand similar to foreign market. Product starts to be transported. And finally, in the third stage it is reached a kind of maturity in terms of demands which has a higher sensitivity compared to the prices. Moreover, by offering a certain degree of standardization of the manufacturing process is also achieved the cost of labor which takes another importance. In this situation it applies to shifts production where labor costs helps to save a considerable amount. The production activity shifts abroad in the second and third "life cycle "of production. ${ }^{5}$

None of the theories that have been examined so far can be considered as a general theory of foreign direct investment.Each of them is based on different assumptions and explanations in various aspects of the phenomenon. Therefore we are talking about each partial theory where each explains an aspect and another different one.

Efforts to create a reference model for the multinational enterprise is made by Dunning (1980, 1988 ). This approach does not seek to explain why or how these investments are realized abroad, but is intended to create a scheme of characteristics and aspects related to the development of FDI to have then a general frame of reference at the moment that will have to nalyzed aspects of this phenomenon. Precisely for this reason, this theory cannot be considered or be included as "General Theory" of multinational enterprises within the microeconomic or macroeconomic theories.

But each theory mentioned above can find a starting point in the Dunning model. This contribution is known as "eclectic paradima". ${ }^{6}$

Dunning starts from the observation that a company can produce for the domestic market to foreign market or both. Company may decide to produce within their country or foreign country to which you want to send the product even in a third country. All these decisions are based on the fact that the company aims to have certain benefits.

\section{Classification of Foreign Direct Investment (FDI)}

There are two main viewpoints in relation to FDI: the one from the perspective of the investor and the one through the eyes of the host country. From the investor's perspective, FDI investments are classified in horizontal, vertical and conglomerate investments.

As regards to the horizontal FDI it means those investments that are produced inside the mother company are produced also in the host country. Therefore, the same standard production is duplicated abroad also.This kind of investment is currently investing the most widespread FDI.

Foreign Direct Investment in the vertical direction is related to transfers of one of the stages of the manufacturing process out of the mother country. This type of investment is more prevalent in secondary and tertiary sectors, such as manufacturing industries.

Also known conglomerate FDI, they are a mix of horizontal and vertical investments, which include investments in an industry of a different nature in the host country. ${ }^{7}$

From the perspective of the host country they are divided into:

\subsection{FDI import substitutes}

These include the production of imported goods that are initially in the host country. This type of investment is influenced by the market, transportation costs and market barriers.

\subsection{FDI rising export}

Mainly related to the search of raw materials or intermediate goods.

\footnotetext{
${ }^{5}$ Vernon R., International investment and international trade in the product cycle, Quarterly Journal of Economics, 80, page. 190-207, 1996.

${ }^{6}$ Dunning J.H., Multinational Enterprises and the Global Economy, Addison-Wesley Publishing Company, 1992.

${ }^{7}$ Caves R.E., Multinational enterprise and economic analysis, Cambridge University Press, Cambridge, Massachussets, 1996.
} 


\subsection{FDI initiated by governments}

This has to do with government policies that offer incentives for foreign investments done in order to eliminate the deficit in the balance of payments.

Given the direction of investment, FDI is divided into two types: internal and external.

$>$ Internal investments are called investments that are made by a foreign entrepreneur in reporting economy, then incoming stock in a given moment of time that refers to all direct investments by non -residents in the reporting economy.

> Foreign Investments are called investments made by a local entrepreneur in another country different from that of residence. Outgoing stocks are investments of reporting economy abroad.

The net inflow of FDI relates to investments over a period of time and is cumulative. This flow (positive or negative) is the result of foreign and domestic investment, also called "stock of foreign direct investment". Negative flow usually shows disinvestments or impact of important foreign reimbursements within the company.

The net inflow of FDI is influenced by the following elements:

\section{$>$ Shareholder Capital}

That is buying the shares of a foreign investor in an entity in the host country.

\section{$>$ Re- investment Capital}

It represents that part of the profit as dividend or split that does not return to the investor, but is used to be reinvested in the host economy.

\section{$>$ Loans within companies}

D They represent short-term or long-term loans between the mother company and its subsidiaries.

Determinant factors of FDI vary depending on the sector, from which they are absorbed, and from the fact whether the market that absorbs is a market of a developing country or a country with market economy already developed.

From a sectoral perspective, the flow of FDI in the primary sector is dependent on macroeconomic factors, development factors, institutional factors and quality. With regard to sectors two and three, in various ways they are affected by the level of national income, the exchange rate change and the development indicators such as financial depth and enrollment in schools, or institutional factors such as judicial independence and flexibility of the labor market. The effect of each of these factors is different depending on economies where they occur, emerging economies and developed economies. ${ }^{8}$

In general, determining factors that influence the choice of country where multinational companies decide to invest, can be classified into two categories:

\section{$>$ associated with the country of origin}

$>$ connected to the host country

Variables associated with the country of origin are factors that make investing abroad more attractive than the one in place, due to the current conditions of the country. Factors associated with the host country make the investment in that country in particular more attractive investment opportunity than in any other country.

\section{Conditions for Withdrawal of Investment}

A place to be attractive to investors must meet certain conditions. Characteristics of the host country should reach much higher profits for the firm and are determinant for the decision to invest abroad. They are many and they vary.

An important theoretical contribution to this issue is given by the "diamond theory ", which is based on four factors that are defined as determinants of country 9 :

$>$ Terms of factors - factors of production include natural reserves as well as those created as skilled labor or infrastructure;

$>$ Demand conditions - the nature of domestic demand for goods and services and the level of customers;

$>$ Related supporting industries - existence on the market of other suppliers or related industries with the investment;

$>$ Strategy, structure and rivalry of the firm - competition of local firms and conditions of creation, organization and management of the company.

\footnotetext{
${ }^{8}$ FMN, James P. Walsh and Jiangyan Yu, 2010.

${ }^{9}$ Twomey, Michael J., A Century of Foreign Investment in the Third World. Routledge., 2000.
} 
These four "diamond "factors, along with the role of government in the economy and the role of chance events, promote or prohibit the creation of competitive conditions for enterprises.

Dunning (1993) argues that the motives and determinants of FDI have changed over time. FDI in developing countries are shifting towards investments from a demanding market requesting towards a demanding FDI of resources and productivity (vertical). Developing countries need to attract FDI using market with size and growth potential. Countries with large markets may be associated with increased FDI due to potential demand and lower costs associated with economies of scale.

Studies conducted by RESMINI $(2000)^{10}$, analyzing FDI in sectors processor it is concluded that the countries of Central and Eastern Europe on population, tend to be more attractive for FDI . In a similar conclusion and Eastrin arrives and Bevan $(2000)^{11}$; economies ( large ) in transition tend to attract more FDI .

It should be emphasized that the market size of a host country cannot be measured only by its population. There may also be other significant factors, especially factors such as purchasing the power of the local population, proximity and links on other sites linked to the existing competition in the host country and more.

\section{Accessing the Country}

On the one hand, the smallest trend in accessing may be associated with an increased horizontal FDI for investment firms to benefit by avoiding investment barriers by raising manufacturing overseas subsidiary.

While the trend of increased access leads to increased flow of vertical FDI as it can be expected in a sector for which international flows of trade in intermediate and capital goods that are important. Even export orientation seems more attractive to FDI and this is related to the growth of trade and FDI flows.

\section{Exchange Rate Evaluation}

A weak exchange rate tends to increase vertical FDI, since the firm has the advantage of lower relative prices in the host countries to buy items, or if the re-exportation of the product, increase benefits in place (home -country) for goods which are send in third markets.

Meanwhile, a strong exchange rate is expected to increase incentives to foreign companies to produce in the country. The exchange rate is somehow a barrier to enter the market and that drives more towards horizontal FDI.

\section{Clustering Effect}

Studies have identified "clustering effect " or " cumulative effect ". Foreign firms seem to be organized with each other through different channels. Projects or different deliveries are seen as a sign of a good business climate for foreign investors. Thus, investors mimic the decisions of other investors choosing to invest in the same direction or sector. This effect is positive for new investors, who benefit from the positive spread of existing investors in the host economy. Such a phenomenon has become known by Wheeler and Mody (1992), the case study of an American company Barrell and Pain $(1999)^{12}$ in Western Europe .

\section{Political Stability}

Political and macroeconomic stability is one of the key issues in terms of the decision on FDI potential. Nonexistence of political stability makes it much less attractive to foreign investors, despite other advantages it can offer. This ranks as the leading factor that gives investors certainty to invest in a particular country. (Schneider and Frey, 1985) ${ }^{13}$

\section{Institutions}

The quality of a country's institutions is palatable determinant of foreign investors, particularly in countries less developed. This happens for some reason:

\footnotetext{
${ }^{10}$ Resmini, L., The European Bank for Reconstruction and Development, 2000.

${ }^{11}$ Alan A. Bevan \& Saul Estrin,, The Determinants of Foreign Direct Investment in Transition Economies, 2000

${ }_{12}$ Barrell, Ray \& Pain, Nigel, "Domestic institutions, agglomerations and foreign direct investment in Europe", 1999

${ }^{13}$ Schneider, F. and Frey, B. "Economic and Political Determinants of Foreign Direct Investment," , 1985
} 
Firstly, good governance is associated with economic growth, which is attractive to inflows of FDI.

Secondly, poor institutions tend to be easily corruptible, thus increasing costs and decreasing investment earnings. Thirdly, the high cost of starting FDls, makes investors more sensitive to uncertainties, including the uncertainties arising from the fragile institutions.

Wheeler and Mody (1992) view and argue that the relationship of FDI with the quality of institutions is different from whether the host country is a developed country or a developing country.

\section{References}

Acocella N., Imprese Multinazionali e Investimenti Diretti: le cause dello sviluppo, 1975.

Acocella N., Strategic Foreign Direct Investment in the EC, Economic Notes, 1991.

Acocella N., L'impresa multinazionale: prospettive per una teoria, 1994.

Aliber R.Z., A theory of foreign direct investment, in Kindleberger ,1970.

Aliber R.Z., The mulinational paradigm, MIT Press,Cambridge, Massachussets, 1993.

Aizenman J., Foreign Direct Investment, Employmentvolatility and cyclical dumping, 1994.

Balasubramanyan V. n., Salisu M., Sapsford D., Foreign Direct Investment and growth in EP and IS countries, The Economic Journal, Vol. 106, pp. 92-105, 1996.

Blomström M., R.E. Lipsey, K. Kulchychy, U.S. and Swedish direct investment and exports, in Baldwin R.E, 1988.

Blomström M., Trasnational corporations and manufacturing exports from developping countries, United Nations Centre on Trasnational Corporations, 1990.

Blomström M., Fors G., Lipsey R.E., Foreign Direct Investiment: home country experience in the United States and Sweden, The Economic Journal, 107, pp.1787-1797, 1997.

Cantwell J.,Teorie dell'internazionalizzazione della produzione, in Acocella N. L'impresa multinazionale: prospettive per una teoria, 1994.

Cantwell J., The globalization of technology: what remains of the product cycle model?, Cambridge Journal of Economics, No. 19, pp. $155-174,1995$.

Caves R.E., Multinational enterprise and economic analysis, Cambridge University Press, Cambridge, Massachussets, 1996.

Civici, A., Globalizimi, 2009.

Convention of the United Nations shall Organized Crime, 2002.

Dunning J.H., Multinational Enterprises and the Global Economy, Addison-Wesley Publishing Company, 1992.

Dunning J. H., The role of foreign direct investment in a globalizing economy,1995.

Dutt A.K., Direct Foreign Investment, Globalization and Northern Growth: Implications of a North-South Model, 1996

Feenstra R.C., Hanson G.H., Foreign investment, outsourcing and relative wages, in Feenstra R.C., Grossman G.M., Irwin D.A.. (eds.), 1996 Political economy of trade policy: Essays in honor of Jagdish Bhagwati , MIT Press, Cambridge, MA, 1996.

Feldestein M., The effects of outbound foreign direct investment on domestic capital stock, NBER Working Paper n.4668, Cambridge, MA, 1994.

Fondi Monetar Ndërkombëtar , 2004.

Hymer S.H., The International Operation of Multinational Firms: A Study of Direct Investment, Ph.D. Thesis, MIT Press. Hufbauer G.C., Adler M., U.S. Manifacturing Investment and the Balance of Payments, Tax Policy Research Study n.1,U.S. Treasury Department, Washington D.C, 1968.

Kalia A., E Drejta Ndërkombëtare Private, 2008 ;

Kodi Civil i Republikës së Shqipërisë , Ligji nr.7850 date 29.03.1996.

Kodi i Proçedurës Civile, Ligji nr.8116 date 29.03.1996.

Kondili,V., E Drejta Civile Pjesa e Posaçme, 2008.

Lall S., Employment an foreign investment: Policy options for develping countries, International Labour Review, 134, pp. 521-540, 1995.

Ligji për Marrëdhëniet Juridiksionale me Shtetet e Huaja, Ligji 10193 date 11.07.2002.

Marrëveshja e Asocim Stabilizimit, 12 qershor 2006.

Menaxhimi i Turizmit, Bakiu V, 2006.

Treaty of Lisbon, december 2009.

Messerlin P.A., The impact of trade and capital movements on labour: evidence on the french case, OECD Economic Studies, n. 24, pp.89-124, 1995.

Për ku je nisur Shqipëria ime?, Velija V., 1996.

Slaughter M.J., Multinational corporations, outsourcing and american wage divergence, NBER Working Paper n.5253, Cambridge, 1999.

Strategjia e zhvillimit të Biznesit dhe Investimeve (2007-2013), 2007

United Nations, World Investment Report, 1998, New York and Geneva, 1998.

Vernon R., International investment and international trade in the product cycle, Quarterly Journal of Economics, 80, pp. 190-207, 1996.

Zhao L., The impact of foreign direct investment on wages and employment, Oxford Economic Papers, 50, pp. 284-301,1998. 